\title{
Heave and Pitch Motions of a Towed Ship in Waves Incorporated with an Asymmetrical Bridle Towline Model
}

\author{
Ahmad Fitriadhy ${ }^{\mathrm{a} *}$, Nurul Aqilah Mansor ${ }^{\mathrm{b}}$, Nur Adlina Aldin ${ }^{\mathrm{c}}$ \\ aProgramme of Maritime Technology, School of Ocean Engineering, University Malaysia Terengganu, Malaysia. Email: naoe.afit@mail.com \\ ${ }^{b}$ Programme of Maritime Technology, School of Ocean Engineering, University Malaysia Terengganu, Malaysia. Email: n.aqilahmansor2@ gmail.com \\ 'Programme of Maritime Technology, School of Ocean Engineering, University Malaysia Terengganu, Malaysia. Email: nuradlina1910@gmail.com
}

\begin{abstract}
Investigation of a ship towing system performance in waves incorporated with an asymmetrical towline configuration is necessarily to be studied to ensure a towing safety of navigation. To achieve the objective, this paper presents the ship towing motion performance in waves using Computational Fluid Dynamic (CFD) approach. Here, the heave and pitch motions of the towed ship so-called barge has been analysed, where several effects of the towing angle and towing speeds have been taken into account. In the calm water condition, the results revealed that the increase of tow angle was proportional with the sufficient reduction of the sway amplitude motion and inversely proportional to her yaw motion. The increase of the asymmetrical tow angle, however, has led to increase her sway motion amplitude in wave condition and conversely reduced the tow speed increased. In addition to the pitch motion characteristic, it subsequently increased by $12.1 \%$ as the tow angle raised from $25^{\circ}$ to $35^{\circ}$; meanwhile the pitch motion of barge has by $10.2 \%$ as the tow speed increased from $0.655 \mathrm{~m} / \mathrm{s}$ to $0.728 \mathrm{~m} / \mathrm{s}$. This CFD simulation is very useful as the preliminary prediction on the heave and pitch motion characteristics ensure a safety navigation of a towed ship in waves
\end{abstract}

Keywords: CFD; heave; pitch; towed ship; waves

\section{Introduction}

Ensuring a safety ship navigation is very crucial to avoid any negative impact during towing of barge such as collision with other ship or onshore structure. The towing instability in term of large heave and pitch motion may occur when the towing of ship exposed to various sea conditions such as wave and wind. Therefore, it is necessary for the barge to keep at steady state for its safety during towing [1] since it do not equipped with active surface control to keep it stable [2].

Several researchers had investigated on the ship towing system configuration of towline model. The study shows that the asymmetrical bridle towline configuration $[3,4]$ has better course stability compared to single [2] $[5,6]$ and symmetrical bridle towline model [3, 7-8]. These course stability of barge had focused on the sway and yaw motion of barge. [9, 10] had predicting the course stability of barge by considering the hydrodynamic forces acting on it. However, the motion characteristic of barge is also important to ensure its safety navigation in waves [11]. The external factor such as waves had significant effect on the course stability of towing system, thus can affect the crew safety [12] and harm goods on board. Few researchers had researched on

\footnotetext{
*Corresponding author. Tel.: +6-09-668-3350

Programme of Maritime Technology, School of Ocean Engineering, Universiti Malaysia Terengganu, 21030 Kuala Terengganu, Terengganu, Malaysia.
}

seakeeping of ship in waves such as [12-15] while [16] had focused more on ship towing in various wave conditions.

Few research methods had been used to investigate the heaving and pitching motion of ship in waves. Those includes numerical approach by $[16,17]$ who studied the seakeeping of ship in waves while $[18,19]$ use the experimental approach. [20] had investigating the heave and pitch motion of structure using experimental approach before simulating the seakeeping analysis by using Computational Fluid Dynamics (CFD). CFD is a reliable and practical tool to solve maritime problem such as ship towing, seakeeping and analysing the ship resistance. There are researchers such as those in $[8,13$, $21,22],[1,3,23,24]$ that have been using the CFD since it can capture the hydrodynamic force and non-linear phenomenon during the simulation $[1,9]$.

This paper proposes an analysis on heave and pitch motion of a towed ship in wave using an asymmetrical bridle towline model by using CFD. The CFD software give more advantages compared to numerical and analytical method as it can capture the non-linear phenomenon during the computation. Besides, it also reduces the computation time and provides more accurate results. Tow angle and tow speed of the barge are taken into account during the simulation to investigate the heave and pitch motion of barge using asymmetrical bridle towline configuration. 


\section{Governing Equation}

FAVOR technique has been applied in Flow3D simulation. In this technique, the computational domain can have multiple moving object which must be in term of solid with no porosity. The tug and barge are both moving object which allow it to be in the same computational domain. Besides, the FAVOR technique treats the complex geometries very efficiently.

A body system (x, y, z) has been set up for each moving object where the coordinate axes parallel with the space system at time $=0$. The origin of the six ${ }^{\circ}$ of freedom $(6 \mathrm{DOF})$ objects have been set up at the object mass center, $G$. the coordinate transformation between space system $(\mathrm{x}, \mathrm{y}, \mathrm{z})$ and body system $\left(\mathrm{x}^{\prime}, \mathrm{y}^{\prime}, \mathrm{z}^{\prime}\right)$ is

$$
\overrightarrow{x_{s}}=[R] \cdot \overrightarrow{x_{b}}+\overrightarrow{x_{G}}
$$

where $\overrightarrow{x_{E}}$ and $\overrightarrow{x_{b}}$ are position vectors of a point in space and body systems, respectively, $\overrightarrow{x_{G}}$ is position vector of the mass center in space system, and $[R]$ is an orthogonal transformation tensor,

$$
[R]=\left[\begin{array}{lll}
R_{11} & R_{12} & R_{13} \\
R_{21} & R_{22} & R_{23} \\
R_{31} & R_{32} & R_{33}
\end{array}\right]
$$

where $R_{i j}, R_{j k}=\delta_{\text {ik }}$ and $\delta_{\text {ik }}$ is the Kronecker $\delta$ symbol. It is a property of $[R]$ that its inverse and transposed matrices are identical. For a space vector Ar, the transformation between the space and body systems is

$$
A_{s}=[R] \cdot A_{b}
$$

where $\overrightarrow{A_{g}}$ and $\overrightarrow{A_{b}}$ denote the $\mathrm{A}$ expressions in space and body systems, respectively. [R] is calculated by solving

$$
\frac{d[R]}{d t}=[\Omega] \cdot[R]
$$

where

$$
[\Omega]=\left[\begin{array}{ccc}
0 & -\Omega_{z} & \Omega_{y} \\
\Omega_{z} & 0 & -\Omega_{x} \\
-\Omega_{y} & \Omega_{x} & 0
\end{array}\right]
$$

and $\Omega_{\mathrm{x}}, \Omega_{\mathrm{y}}$ and $\Omega_{\mathrm{z}}$ are the $\mathrm{x}-\mathrm{y}$ - and $\mathrm{z}$-components of the angular velocity of the object in space system, respectively.

FLOW-3D solves Navier-stokes type equations embedded with various turbulence models. This simulation used the RNG turbulence model since it consider the low Reynold number effects. [25-27]. Applying the double averaging strategy to the transport equations for TKE and its dissipation rate produces the turbulence model for the flow. The resulting equations are:

$$
\begin{gathered}
\frac{\delta k}{\delta t}+U_{j} \frac{\delta k}{\delta x_{j}}=\frac{\delta}{\delta x_{j}}\left[\left(v+\frac{v_{t}}{\sigma_{k}}\right) \frac{\delta k}{\delta x_{j}}\right] \\
+P_{k}+B_{k}+W_{k}-\varepsilon \\
\frac{\delta \varepsilon}{\delta t}+U_{j} \frac{\delta \varepsilon}{\delta x_{j}}=\frac{\delta}{\delta x_{j}}\left[\left(v+\frac{v_{t}}{\sigma_{\varepsilon}}\right) \frac{\delta \varepsilon}{\delta x_{j}}\right] \\
+C_{1 \varepsilon} \frac{\varepsilon}{k}\left(P_{k}+B_{k}\right)\left(1+C_{3 \varepsilon} R_{f}\right)+W_{k}-C_{2 \varepsilon}^{*} \frac{\varepsilon^{2}}{k} \\
P_{k}=v_{t} S^{2}=v_{t}\left(\frac{\delta U_{i}}{\delta x_{j}}+\frac{\delta U_{j}}{\delta x_{j}}\right) \frac{\delta U_{i}}{\delta x_{j}} \\
B_{k}=\beta g_{i} \frac{v_{t}}{\sigma_{s}} \frac{\delta s}{\delta x_{j}}
\end{gathered}
$$

where $P_{k}$ is the shear production term of TKE, $S=\sqrt{2 S_{i j} S_{j i}}$ is the modulus of the mean rate of strain tensor and $S_{i j}=\frac{1}{2}\left(\frac{\delta U_{i}}{\delta x_{j}}+\frac{\delta U_{j}}{\delta x_{i}}\right), B_{\mathrm{k}}$ is the buoyant production term of TKE, $W_{k}$ is the wake production tern of TKE, $W_{\varepsilon}$ is the wake production term in $\varepsilon_{s} \sigma_{k}$ and $\sigma_{\varepsilon}$ are the turbulent Prandtl numbers for $k$ and $\varepsilon$, and $C_{i \varepsilon}$, $C_{3 \varepsilon}$ and $C_{2 \varepsilon}^{*}$ are model coefficients.

Stokes and Cnoidal wave generator (Fourier Series Method) is used since it both provides higher-order accuracy. The wave speed $\mathrm{c}$ and the angular wave frequency are related to other parameters as

$$
\begin{aligned}
& c=\frac{\lambda}{T} \\
& \omega=\frac{2 \pi}{T}=c k
\end{aligned}
$$

where:

- $\lambda$ is the wavelength,

- $k$ is the wave number, $k=\frac{2 \pi}{\lambda}$

- $T$ is the wave period.

Table 1. Barge dimension

\begin{tabular}{|c|c|}
\hline Description & Dimension \\
\hline Length $l,(\mathrm{~m})$ & 1.221 \\
\hline Breadth $b,(\mathrm{~m})$ & 0.213 \\
\hline Draft $d,(\mathrm{~m})$ & 0.0548 \\
\hline Volume $V,\left(\mathrm{~m}^{3}\right)$ & 0.02634 \\
\hline$L / B$ & 2.86 \\
\hline Block coefficient $\mathrm{C}_{\mathrm{b}}$ & 0.92 \\
\hline
\end{tabular}




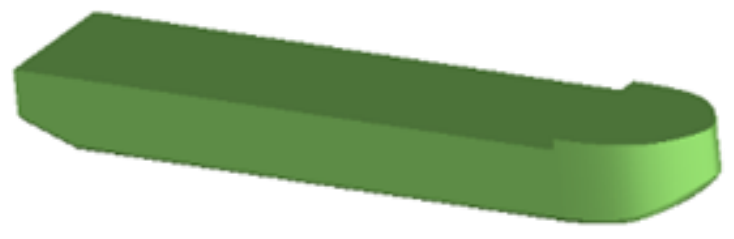

(a) Barge model

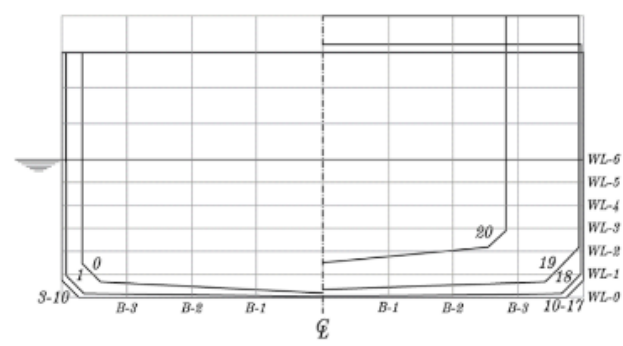

b) Barge body plan

Figure 1. Barge model and body plan used in CFD simulation

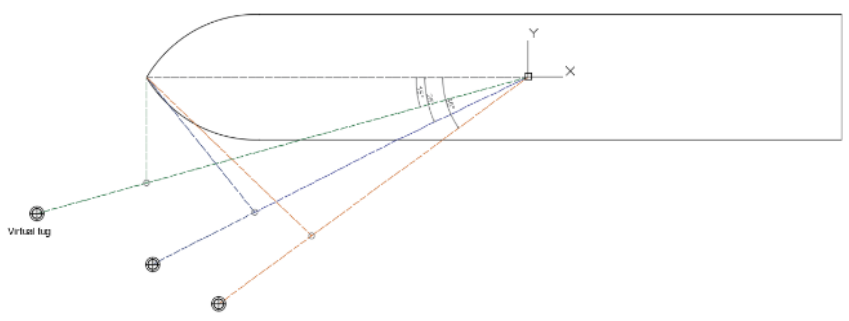

Figure 2. Simulation condition of barge

Table 2. Barge's towing parameter in various tow angle

\begin{tabular}{ccc}
\hline Tow angle & Wavelength $(\lambda / \mathrm{Lpp})$ & Tow speed $(\mathrm{m} / \mathrm{s})$ \\
\hline $5^{\circ}$ & & \\
\hline $15^{\circ}$ & 1.0 & 0.509 \\
\hline $25^{\circ}$ & & \\
\hline $35^{\circ}$ & & \\
\hline
\end{tabular}

Table 3. Barge's towing parameter in various tow speed

\begin{tabular}{ccc}
\hline Tow speed $(\mathrm{m} / \mathrm{s})$ & Wavelength $(\lambda / \mathrm{Lpp})$ & Tow angle \\
\hline 0.509 & & \\
\hline 0.582 & & $25^{\circ}$ \\
\hline 0.655 & 1.0 & \\
\hline 0.728 & & \\
\hline
\end{tabular}

\section{Simulation Condition}

\subsection{Principle data of ship}

The dimension of the barge is presented in Table 1 while the barge model used in the CFD simulation is shown in Fig.1.

\subsection{Simulation parameters}

Figure 2 shows the towing condition of the towed barge. The tug is replaced with the sphere body by using similar characteristics of tug to reduce the computational time during simulation. The simulation parameters used in this analysis are shown in Table 2 and 3. The tow angle used are $5^{\circ}, 15^{\circ}, 25^{\circ}$ and $35^{\circ}$ with tow speed 0.509 $\mathrm{m} / \mathrm{s}, 0.582 \mathrm{~m} / \mathrm{s}, 0.655 \mathrm{~m} / \mathrm{s}$ and $0.728 \mathrm{~m} / \mathrm{s}$. The wavelength $(\lambda / \mathrm{Lpp})$ used is $1.0 \mathrm{~L}$ in constant wave height at $0.03 \mathrm{~m}$.

\subsection{Computational domain and meshing generation}

The computational domain of the barge associated with the number of meshing cell in the CFD. The total number of cells used in the simulation is 1 million cells. Referring to Fig.3, the boundary conditions are mark in the mesh blocks. For mesh block 1, the boundary condition at X-max boundary is defined by wave to allow the wave to enter the boundary. The velocity used in the simulation is constant by $0.509 \mathrm{~m} / \mathrm{s}$ for the sphere model. $\mathrm{X}$-min, Y-max and Y-min is defined by outflow boundary to absorb the wave motion which will reduce the reflection from the boundary while Z-min using symmetry boundary which it applies zero-gradient condition at the boundary and Z-max using specified pressure to create a uniform pressure in the boundary. All mesh boundary for mesh block 2 are defined by symmetry. The boundary conditions for this simulation are as shown in Table 4 and Fig.3(a). The meshing scheme is also shown in Fig.3(b).

The barge is coupled through a towline. Sphere model which acted as the tow ship is assigned as prescribed motion while barge as towed ship is set as coupled motion in $\mathrm{X}$ translational, $\mathrm{Y}$ translational and $\mathrm{Z}$ rotational motions (surge, sway and yaw as this simulation is considering 3 degree of freedom. The towline is set as mooring line characteristic with spring coefficient of $7.347 \mathrm{~kg} / \mathrm{s}^{2}$.

Based on the applications of FLOW3D v11.0.4, the average duration of every simulation was about 70-80 hours (4 parallel computations) on a HP Z820 workstation PC with processor Intel (R) Xeon (R) CPU ES-2690 v2 @ $3.00 \mathrm{GHz}$ (2 processors) associated with the installed memory of $32.0 \mathrm{~GB}$ and 64-bit Operating System.

Table 4. Boundary Conditions

\begin{tabular}{ccc}
\hline Boundary & Mesh block 1 & Mesh block 1 \\
\hline $\mathrm{X}_{\min }$ & Wave & Symmetry \\
\hline $\mathrm{X}_{\max }$ & Outflow & Symmetry \\
\hline $\mathrm{Y}_{\min }$ & Outflow & Symmetry \\
\hline $\mathrm{Y}_{\max }$ & Outflow & Symmetry \\
\hline$Z_{\min }$ & Symmetry & Symmetry \\
\hline$Z_{\max }$ & Specified pressure & Symmetry \\
\hline
\end{tabular}

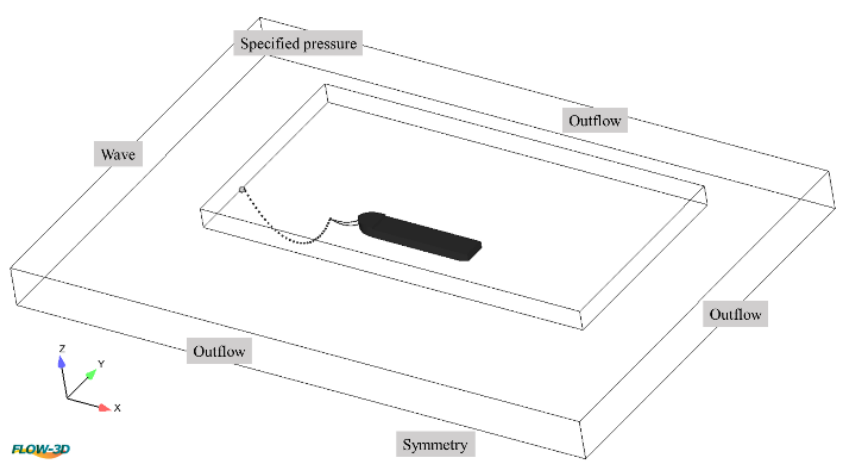

a) Boundary condition 


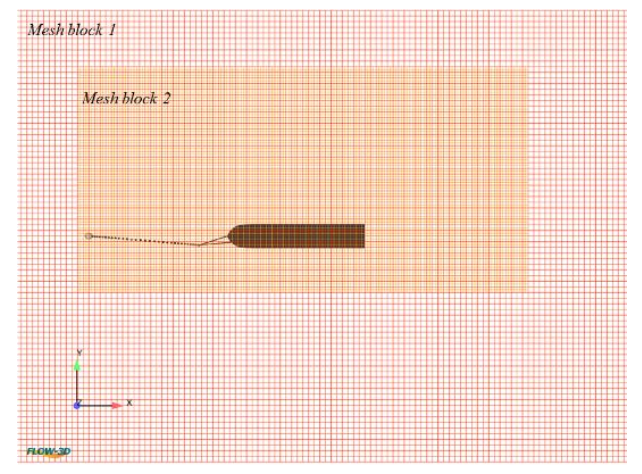

b) Meshing generation

Figure 3. Boundary condition (a), and meshing generation (b) of barge

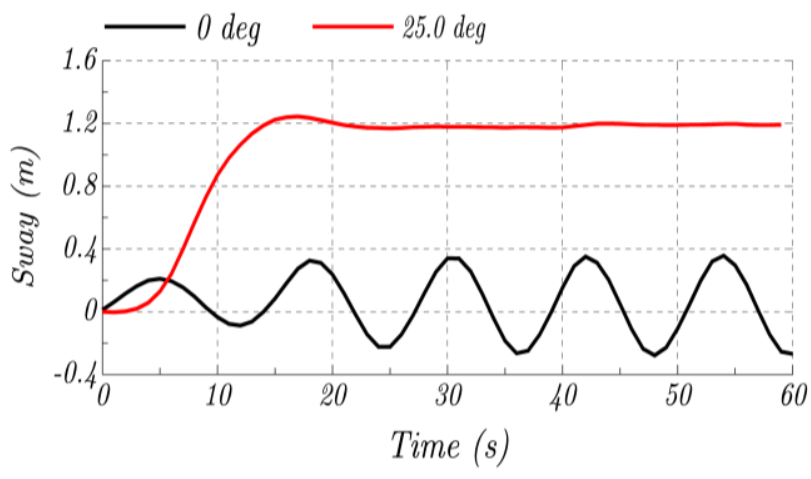

Figure 4. Effect of sway motion using single towline $\left(0^{\circ}\right)$ and asymmetrical bridle towline $\left(25^{\circ}\right)$

\subsection{Analysis of results of tow angle $0^{\circ}$ and $25^{\circ}$}

Applying asymmetrical bridle towline configuration during towing will reduce the sway motion of the towed ship. Figure 4 shows the sway motion graph of tow angle $0^{\circ}$ and $25^{\circ}$.

Comparing this asymmetrical bridle towline configuration and straight tow $\left(0^{\circ}\right.$ of the tow angle $)$, the results show significant different of the slewing motion of barge. this can be proven by the researches from [3] [4] who stated that the increase of tow angle had reduce the slewing motion of barge. Even though their research is in calm water, the results of the sway motion show similar trend when the barge is towing in waves. The simulation of tow angle $0^{\circ}$ and $25^{\circ}$ had been run to prove that the theory that the increase of tow angle had reduce the slewing motion of barge.

\section{Results and Discussions}

\subsection{Effect of tow angle on heave and pitch motions of} barge

The simulation of heave and pitch motion on asymmetrical bridle towline configuration has been done by using CFD. The simulation result is presented along with the effect of sway, heave, pitch, yaw and towline tension of barge. Figure 5 shows the results of the sway, heave, pitch, yaw and towline tension of barge during towing in waves.

The average sway motion amplitude of barge has decreased as the tow angle increases from $5^{\circ}$ to $35^{\circ}$. It should be noted here that the barge has the higher sway motion amplitude of $0.31 \mathrm{~m}$ at the tow angle of $5^{\circ}$ as compared to the larger tow angles. This can be validated by the research from [3] who stated that the increase of tow angle has decreased the sway motion of barge. In addition, the heave motion amplitude of barge has decreased as the tow angle increases. Here, the results show that the maximum decrement of heave motion occurred when the tow angle subsequently increases from $15^{\circ}$ up to $25^{\circ}$. Besides, the average yaw motion of barge also increased as the tow angle increase from $15^{\circ}$ to $35^{\circ}$. The significant increase of the average yaw motion of the barge by $32.4 \%$ occurred as the tow angle increased from $15^{\circ}$ to $25^{\circ}$.

Referring to Fig.6, the CFD visualization has been presented in the form of the wave fluid elevation of fluid at various tow angles. Here, the ratio of $\lambda / \mathrm{Lpp}$ has been constant of 1.0. As seen, the increase of the tow angle resulted in the higher wave crest (red color) at the barge's port. This means that the pressure at the port side increased. Consequently, the resistance of barge increases, which inherently resulted in the increment of the towline tension as the tow angle subsequently increases up to $35^{\circ}$.

\subsection{Effect of tow speed on heave and pitch of barge}

As seen in Fig.7, the effect of the tow speed on the sway, heave, pitch and yaw motions of barge incorporated with the asymmetrical bridle towline model have been analysed. The results showed that the sway motion amplitude of the barge has led to be steady at the tow angle of $25^{\circ}$. Besides, the yaw motion has gradually decreased, where the maximum reduction of the sway motion amplitude of the barge by $5.4 \%$ as the tow speed increases from $0.582 \mathrm{~m} / \mathrm{s}$ to $0.655 \mathrm{~m} / \mathrm{s}$. Meanwhile, the heave and pitch motion amplitudes of the barge has decreased by $2.26 \%$ and $10.2 \%$, respectively, as the tow speed increased from $0.655 \mathrm{~m} / \mathrm{s}$ to $0.728 \mathrm{~m} / \mathrm{s}$. Referring to the results, the magnitude of the towline tension has proportionally increased with respect the increase of the tow speed, where its maximum increment of $19.54 \%$ occurred as the tow speed increased from $0.509 \mathrm{~m} / \mathrm{s}$ to $0.582 \mathrm{~m} / \mathrm{s}$. 

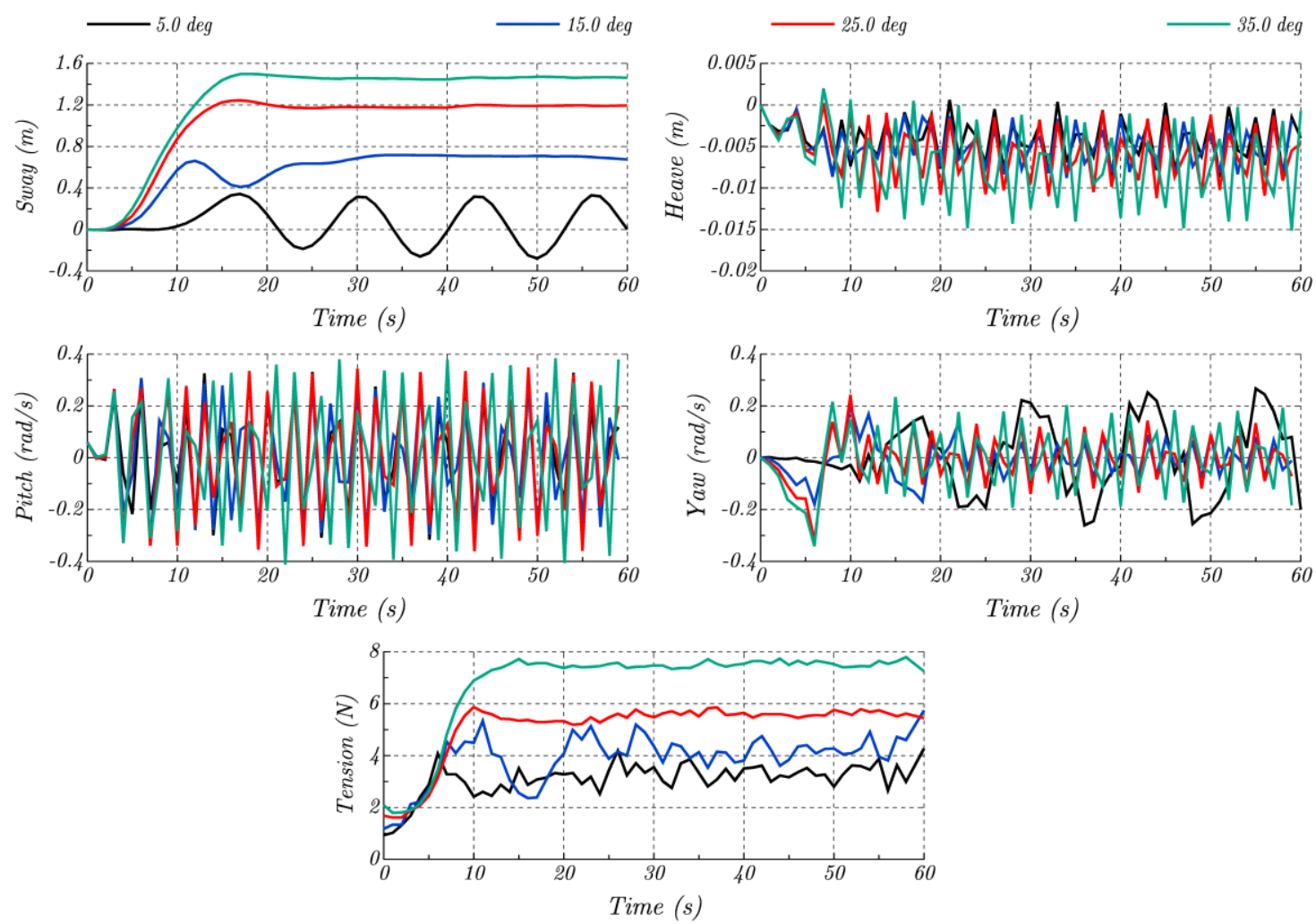

Figure 5. Effect of sway, heave, pitch, yaw and towline tension in various tow angle at constant tow speed $0.509 \mathrm{~m} / \mathrm{s}$

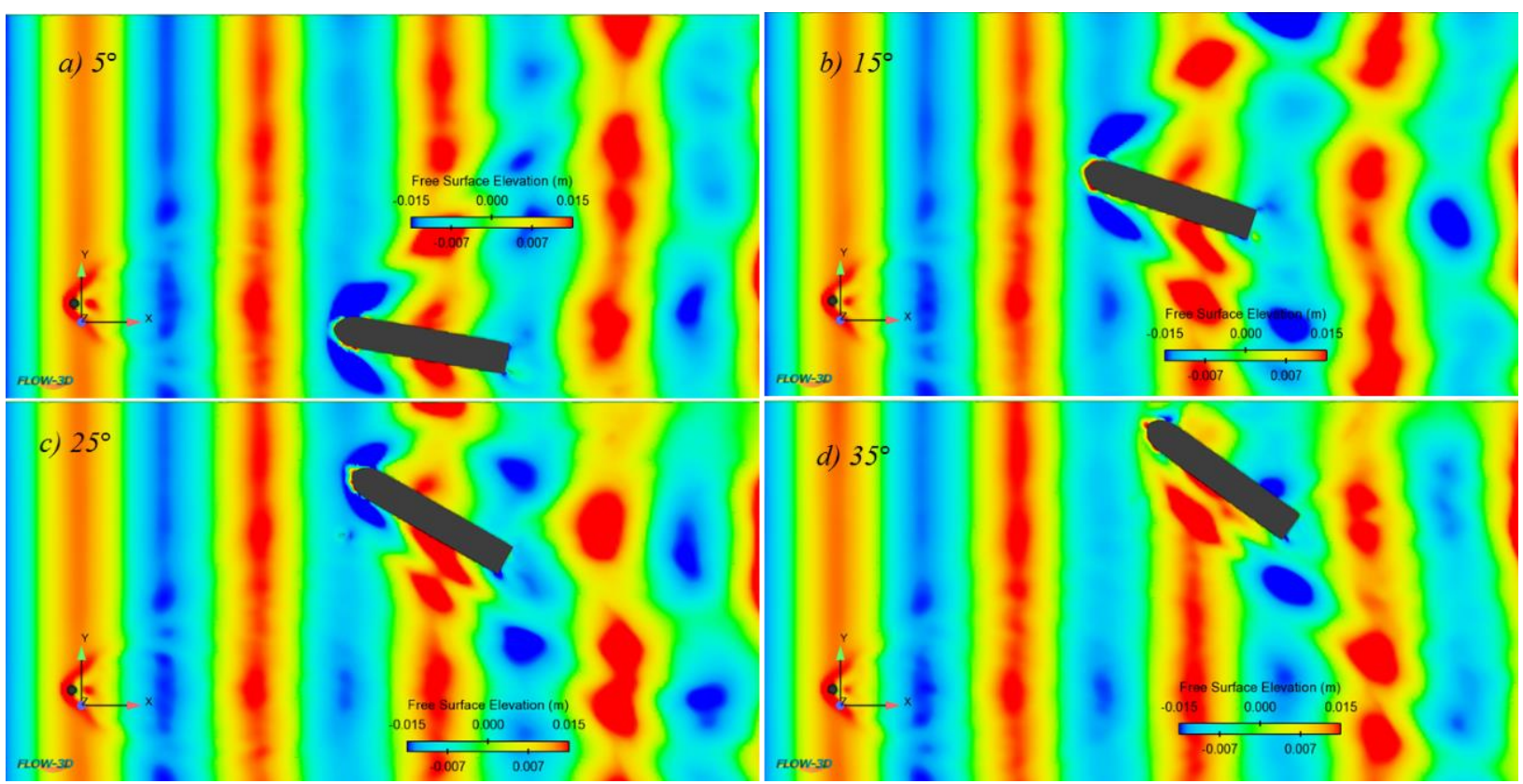

Figure 6. CFD visualisation of various tow angle in wavelength, $\lambda / \mathrm{Lpp}=1.0$ at constant tow speed $0.509 \mathrm{~m} / \mathrm{s}$ 

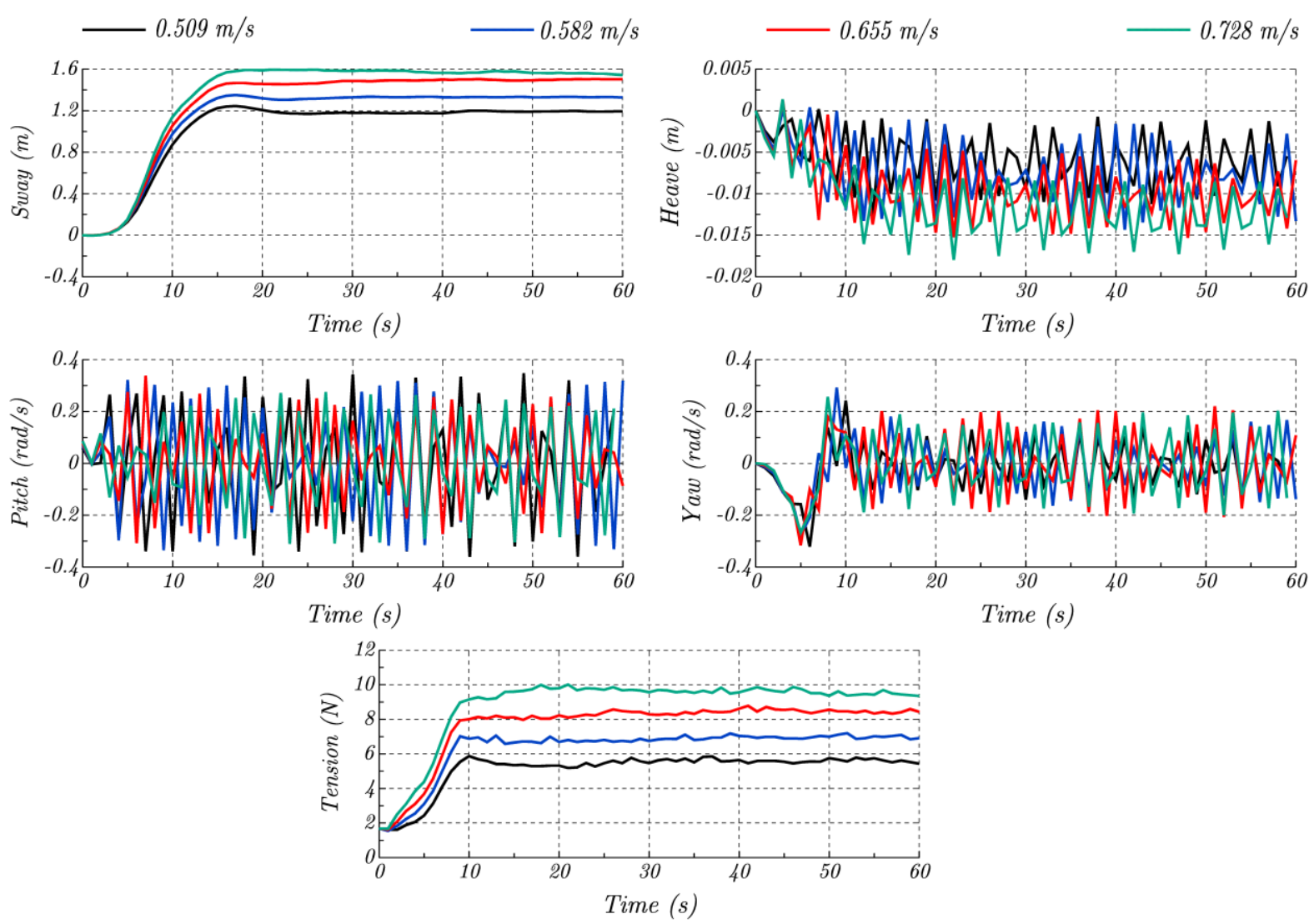

Figure 7. Effect of surge, sway, heave, pitch and towline tension in various tow speed at constant tow angle $25^{\circ}$

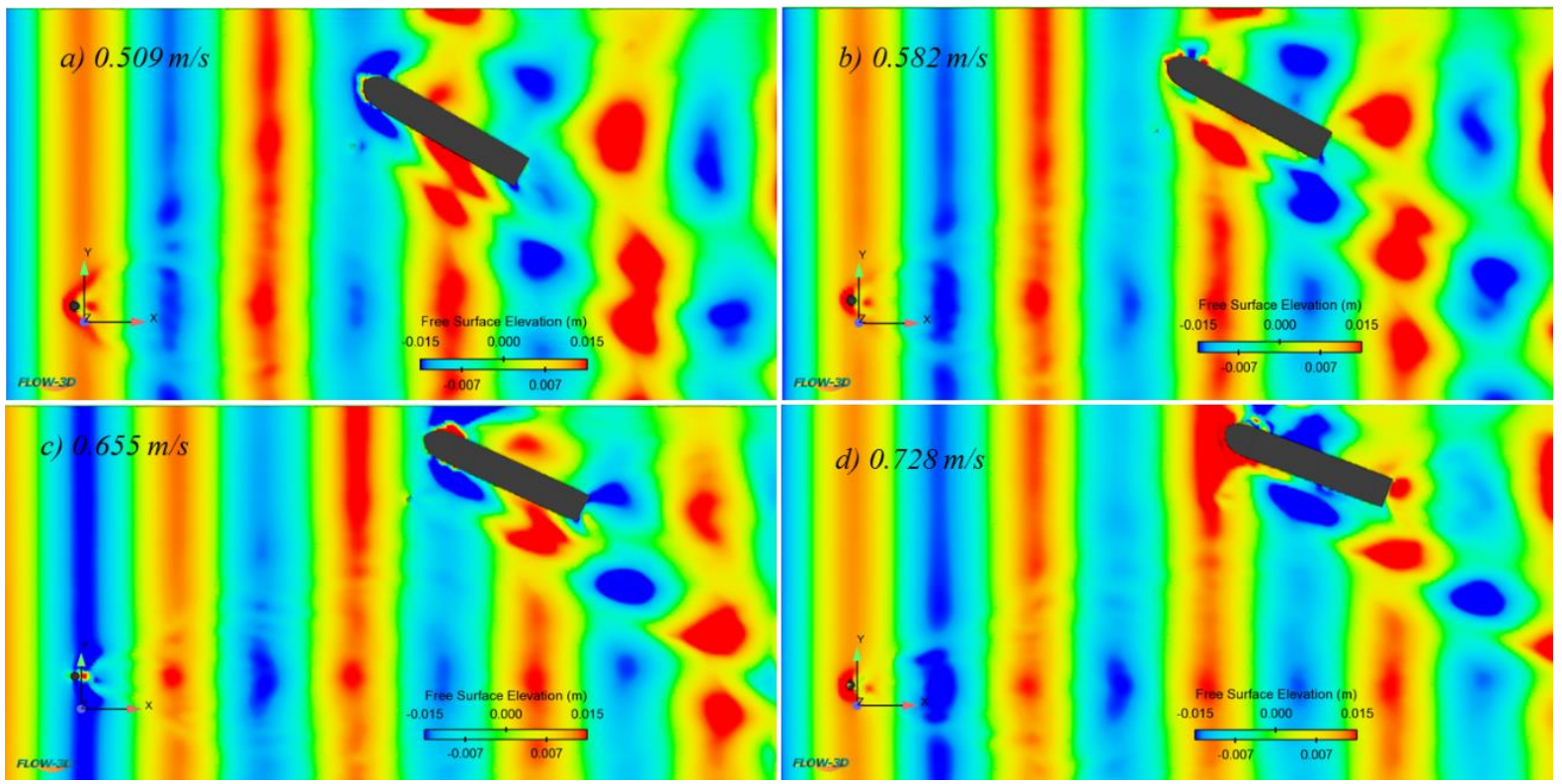

Figure 8 . CFD visualisation of various tow speed in wavelength, $\lambda / \mathrm{Lpp}=1.0$ at at constant tow angle $25^{\circ}$

Figure 8 shows the CFD visualisation of the barge during simulation at various tow speeds. The wave crest (red color) of the barge's bow increased as the tow speed increased from $0.509 \mathrm{~m} / \mathrm{s}$ to $0.728 \mathrm{~m} / \mathrm{s}$. This is due to higher resistance (see Figure 7) which predominantly caused by the increase of pressure at the bow. As a result, this hydrodynamic phenomenon has resulted in the increase of towline tension to tow the barge during towing.

\section{Conclusion}

The analysis of heave and pitch motion of the towed ship incorporated with the asymmetrical bridle towline model has been carried out using the Computational Fluid Dynamic approach. Here, the effect of the tow angle and tow speed on the performance of the heave and pitch motions of the barge have been taken into account 
at a wide range of tow angles and tow speeds. Several simulation results have been concluded as follows;

- The characteristics of the sway and yaw motion amplitude of the barge in waves have seemed with in calm water condition.

- In addition to heave and pitch motions of the barge has decreased by $2.26 \%$ and $10.2 \%$, respectively, as the tow speed increases from $0.655 \mathrm{~m} / \mathrm{s}$ to $0.728 \mathrm{~m} / \mathrm{s}$.

- Besides, the increase of tow speed is also proportional with the increase of the towline tension magnitude, where the maximum increment of the towline tension is $19.54 \%$ as the tow speed increases from $0.509 \mathrm{~m} / \mathrm{s}$ to $0.582 \mathrm{~m} / \mathrm{s}$. This can be explained by the CFD visualization that the pressure increases, which result in the increase of her resistance.

\section{References}

[1] Lee, S. and C. Hong, Study on the Course Stability of Very Large Vessels in Shallow Water Using CFD. Ocean Engineering, 2017. 145: p. 395-405.

[2] Lee, M.-L., Dynamic Stability of Nonlinear Barge-towing system. Applied mathematical modelling, 1989. 13(12): p. 693-701.

[3] Zan, U.I., et al., Model Experimental Study of a Towed Ship's Motion. Journal, 2012.

[4] Fitriadhy, A., et al., Analysis of an Asymmetrical Bridle Towline Model to Stabilise Towing Performance of a Towed Ship. Jurnal Teknologi (Sciences \& Engineering), 2014. 66(2): p. 151-156.

[5] Bernitsas, M. and N. Kekridis, Simulation and Stability of Ship Towing. International Shipbuilding Progress, 1985. 32(369): p. 112-123.

[6] Kijima, K. and Y. Wada, Course stability of towed vessel with wind effect. Journal of the Society of Naval Architects of Japan, 1983. 1983(153): p. 117-126.

[7] Fitriadhy, A. and H. Yasukawa, Turning Ability of a Ship Towing System. Ship Technology Research, 2011. 58(2): p. 112-124.

[8] Fitriadhy, A., et al., Computational Fluid Dynamics Analysis on the Course Stability of a Towed Ship. Journal of Mechanical Engineering and Sciences, 2017. 11(3): p. 2919-2929.

[9] Im, N., S. Lee, and C. Lee, The Influence of Skegs on Course Stability of a Barge with a Different Configuration. Ocean Engineering, 2015. 97: p. 165-174.

[10] Fitriadhy, A., H. Yasukawa, and K. Koh, Course Stability of a Ship Towing System in Wind. Ocean Engineering, 2013. 64: p. 135-145.

[11] Nakayama, Y., et al. Time Domain Simulation OfWave-induced Motions of a Towed Ship In Head Seas. in The Twenty-second International Offshore and Polar Engineering Conference. 2012. International Society of Offshore and Polar Engineers.
[12] McTaggart, K., et al., Seakeeping of two ships in close proximity. Ocean engineering, 2003. 30(8): p. 1051-1063.

[13]Fitriadhy, A. and N.A. Adam, Heave and Pitch Motions Performance of a Monotricat Ship in Head-seas. International Journal of Automotive and Mechanical Engineering, 2017. 14: p 4243-4258.

[14] Skejic, R., Maneuvering and seakeeping of a single ship and of two ships in interaction. 2008.

[15]Fang, M.-C. and J.-H. Ju, The dynamic simulations of the ship towing system in random waves. Marine Technology, 2009. 46(2): p. $107-115$.

[16] Milgram, J.H., M.S. Triantafyllou, and F.C. Frimm, Seakeeping and extreme tensions in offshore towing. Society of Naval Architects and Marine Engineers-Transactions, 1988. 96

[17] Seo, M.-G. and Y. Kim, Numerical analysis on ship maneuvering coupled with ship motion in waves. Ocean engineering, 2011. 38(17-18): p. 1934-1945.

[18] Islam, M., F. Jahra, and S. Hiscock, Data Analysis Methodologies for Hydrodynamic Experiments In Waves. Journal of Naval Architecture \& Marine Engineering, 2016. 13(1).

[19] Dumez, X. and S. Cordier. Accuracy of wave pattern analysis methods in towing tanks. in 21st Symposium on Naval Hydrodynamics. 1997.

[20]Habekost, T., et al. Experimental and Numerical Seakeeping Analysis of a Mobile Offshore Application Barge (MOAB®). in The Twenty-second International Offshore and Polar Engineering Conference. 2012. International Society of Offshore and Polar Engineers.

[21]Fitriadhy, A., et al., Computational Fluid Dynamics Investigation on Total Resistance Coefficient of a High-speed" Deep-V" Catamaran in Shallow Water. International Journal of Automotive and Mechanical Engineering, 2017. 14: p. 4369-4382.

[22] Fitriadhy, A., P. Lim, and A. Jamaluddin. CFD Investigation on Total Resistance Coefficient of Symmetrical and Staggered Catamaran Configurations through Quantifying Existence of an Interference Factor. in International Conference on Ships and Offshore Structures. Hamburg, Germany. 2016.

[23] Oldfield, C., et al. Prediction of Warship Manoeuvring Coefficients using CFD. in World Maritime Technology Conference. 2015.

[24] Yaakob, O., et al., Determining Ship Resistance Using Computational Fluid Dynamics (CFD). Journal of Transport System Engineering, 2015. 2(1): p. 20-25.

[25] Yakhot, V. and S.A. Orszag, Renormalization group analysis of turbulence. I. Basic theory. Journal of scientific computing, 1986. 1(1): p. 3-51.

[26] Yakhot, A., S. Rakib, and W. Flannery, Low-Reynolds Number Approximation for Turbulent Eddy Viscosity. Journal of Scientific Computing, 1994. 9(3): p. 283-292.

[27] Koutsourakis, N., J.G. Bartzis, and N.C. Markatos, Evaluation of Reynolds Stress, $k-\varepsilon$ and $R N G k$ - $\varepsilon$ Turbulence Models in Street Canyon Flows Using Various Experimental Datasets. Environmental fluid mechanics, 2012. 12(4): p. 379-403. 